\title{
Needs Analysis of Blended Learning Media to Improve Students Mathematical Creative Thinking Skills of Mathematics Student by using the Mentimeter Application
}

\author{
Ade Andriani ${ }^{1}$, Izwita Dewi ${ }^{2}$, Prihatin Ningsih Sagala ${ }^{3}$ \\ $\left\{\right.$ adeandriani@unimed.ac.id ${ }^{1}$,dewi_lubis62@yahoo.co.id ${ }^{2}$,sabikhah_81@yahoo.com ${ }^{3}$ \}
}

Department of Mathematics, State University of Medan, Medan, Indonesia ${ }^{123}$

\begin{abstract}
This research is the first step (preliminary study) in the research of the development of learning media to improve students' creative mathematical thinking skills by using mentimeter applications. In general, the purpose of this research is to describe the needs of learning media based on Blended learning using a mentimeter application. In detail, the purpose of this research is to describe (1) the characteristics of the mathematics education curriculum (2) the early ability of students, is students' creative thinking abilities and (3) the use of Mentimeter applications in learning. This research was carried out at the State University of Medan with research subjects were 23 students and four lecturers from the mathematics department. The research method used is descriptive qualitative with the research instrument are a form of observation, the interview, and the student's creative thinking ability test. From the results of data analysis, it can conclude that it is necessary to develop learning media based on Blended learning to improve students' creative thinking ability by using mentimeter applications.
\end{abstract}

Keywords: Mentimeter Application, Mathematical Creative thinking Skills.

\section{Introduction}

We understand together that technology has progressed continuously, from the Baby Boomers generation to the generation which known as an alpha generation. The first goal of it developing this technology is to help human work become more effective and efficient, it can see with a handphone can do various things such as buying and selling transactions, sharing news or information can be only in seconds.

Seeing the reality of technology development, as experts and education technicians should be begun to change the educational projection. As said by the Governor of DKI Jakarta who is also a former Minister of Education, Mr. Anis Baswedan at the 2017 EXPO Education event at TMII, among his statements is that 21st Century Education Projections consist of 3 components, one of which is related to technology literacy. (Maryland State Department of Education, 2005) Technology literacy is the ability to use, understand, organize and assess an innovation that involves processes and knowledge to solve problems and expand one's abilities. In education, technology literacy is the ability that consists of aspects of science, critical thinking skills, and decision making to effectively utilize technology/innovation of human works, especially in the world of education. 
One educator is a lecturer, who has responsibility for the quality of output from a college. Based on law no. 14 of 2005 , lecturers are professional educators and scientists with the main task of transforming, developing, and disseminating science, technology, and art through education, research and community service. This task is called the Tri Dharma college. But in the implementation it, the lecturer has problems. One of the problems is the limited time in the implementation of these three tasks. The researcher who is a lecturer in mathematics at the Medan State University found that there is often a similarity in the schedule of lecturers in the field of teaching with a schedule of researching or serving. There is the ineffectiveness of the lecturers' performance or task of the lecture, not accord rules and regulations.

This performance that not maximum certainly affects students, especially in the field of learning. Finally, made to the low level of student participation. One of the expected achievements is the high ability of students to think, especially for mathematics students, the ability to think creatively is processability that must be stimulated by a lecturer so that students are accustomed to creative thinking.

There are many ways that education experts have begun to develop to minimize these problems, one of which is by use technology such as Blended learning. Blended learning is a learning model that combines learning in class with online learning. So that theoretically a lecturer can teach online when the schedule is same with research or service. Blended learning can do by utilizing several applications such as web applications, Memntimeters and Whatsapp.

But the solution has not been implemented optimally, what are the obstacles? Is it true that learning with the blended model is needed specifically at Medan State University? Based on this, researchers are interested in analyzing the need for developing media to improve students' creative mathematical abilities using the Mentimeter application.

\section{Review Of Literature}

In analyzing the needs of media learning based on blended learning with the aim of improving students' creative thinking ability by using the Mentimeter application. The researcher will define some related things, namely Blended Learning, Mentimeter Application, Creative Thinking Ability.

\subsection{Learning Media}

Learning media is an important matter for improving the quality of education. Learning media according to some expert, (Rudi and Cepi, 2008) explains that learning media are "messenger technologies that can use for learning purposes." suggests that learning media are "physical means to share learning content/materials such as books, films, videos, slides, etc.".

Learning media is a tool in the learning process inside and outside the classroom, further explained that learning media is a component of learning resources or physical vehicles that contain instructional material at the student environment that can stimulate students to learn. (Azhar, 2011)

Learning media everything that can be used to channel messages from the sender to the recipient of the message. (Arief Sadiman, 2008). According to the exposure of some of these experts, the learning media in this study is a tool to share learning material from educators to students in the learning process, so that learning can do effectively and efficiently. 


\subsection{Blended Learning}

Etymologically, Blended Learning consists of two words, Blended and Learning. " blend " means a mixture, or a combination of formula. " learning " is learning, so that Blended Learning means learning which has to combine one model with another model. According to saying (Graham, 2004): “...The idea that Blended Learning is the combination of instruction from two historically separate models of teaching and learning: traditional face to face learning systems and distributed learning systems. It also emphasizes the central role of computer-based technologies in Blended Learning".

"Blended learning is defined as a mix of traditional face-to-face instruction and elearning (Koohang, 2009).

Then According to Mosa (Rusman, 2011) said that mixed learning has two main elements, first is learning in class and second is online learning. In the online learning use the internet network which there is web-based learning. Blended Learning is a combination of multimedia technology, CD-ROM, video streaming, virtual classes, e-mail, voicemail, and others with traditional classroom learning. Its conclude is merging or mixing two learning approaches that are used so that new learning is created and will not cause students bore.

In this research blended learning is a combination of two learning, is learning in the classroom with learning outside the classroom by utilizing the mentimeter application.

\subsection{Creative Thinking Ability}

Creative thinking is the ability to form new combinations, based on data or information, or elements that already know before, all the experience and knowledge that a person has got during life both in school, family, and community. (Munandar, 2012). Indicators of creative thinking abilities (Munandar, 2009), there are 4, (1) Fluency thinking if they can provide more than one relevant idea, and the solution is correct and clear, (2) Students have the ability to think flexibly, if it can provide answers more than one way (diverse), the calculation process and results are correct, (3) Students have the ability to think original (Originality), if they can give answers in their way, the calculation process and results are correct, and (4) Students have the ability to think in detail (Elaboration) if they can provide correct and detailed answers.

Assessment of the to creative mathematics think ability (creative mathematical thinking) according to Silver (Siswono, 2007) using The Torrance Tests of Creative Thinking (TTCT). Three key components assessed in using TTCT are fluency, flexibility, and novelty. Fluency refers to the number of ideas created in response to a command. Flexibility is seen in changes in approach when responding to commands. Novelty is the authenticity of ideas created in response to commands.

\subsection{Mentimeter Application}

Mentimeter is an application that is easy to download. By connecting devices both mobile and laptop to the network, its application can download. Mentimeter is used for percentages in seminars, workshops, or events with presenters and audiences. Different from powerpoint, this application is more fun, interactive, and productive. There are tools so that the audience can respond directly to the presenter. Like there are questions submitted by the presenter, the audience only gives answers to questions via cell phone or tablet. Answer results are displayed in real-time directly on the slide. 
Using Mentimeter application in the class have to function are (Cikgusiber.com,2018)

1. Stimulate Thinking

The use of Mentimeter can stimulate and attract students' attention to the material they want to learn. This application can be developed creatively to make learning interactive and meaningful.

2. To express opinions or views

Orally Giving opinions and views is the best way to improve oral communication skills. But this is difficult for shy students to share their idea.. with 'anonymous' at Mentimeter, students can share many their idea so that can develop quality dan data. They can quantify an idea

3. Tools for Reflection

With the Mentimeter, the teacher can measure and assess the overall learning that has been done. At the end of the meeting, students can give comments about their understanding, impressions in today's learning or give questions if something is not understood.

4. Tools for Research

Students can use Mentimeter as a tool to collect design research as an outside learning activity in the classroom. Each experimental data is collected and then presented to the class.

\section{Methodology}

The method used in this research is qualitative descriptive. Qualitative descriptive research is research to understand the phenomenon of what is experienced by the research subject of such as behavior, perception, motivation, action, etc. holistically and with the description with words and language, in a special natural context and by utilizing various methods scientific.

This research was conducted in the department of mathematics, Medan state university. With the subject of his research were four mathematics education lecturers and 23 mathematics education students. Data collection techniques used are tests and non-tests, the tests given are tests of creative thinking skills while non-tests are in the form of questionnaires for learning needs using media based on blended learning, interviews, and observations.

The observation phase, the researcher analyzed the curriculum used in education units and student characteristics. Then at the interview stage and questionnaire, the need for learning media based on Blended learning was given for lecturers and students. The test is only given to students.

Questionnaires data analyzed using the following formula:

Percentage $=\frac{\mathrm{A}}{\mathrm{B}} \times 100 \%$

Information :

A : The proportion that chooses

B : Amount (respondent)

The data of creative thinking ability was analyzed by classifying these abilities into the level of mathematical creative thinking ability (Very Creative, creative, quite creative, and not creative). 
Table 1. The rubric of creative thinking ability.

\begin{tabular}{rccc}
\hline Level & Fluency & Flexibility & Novelty \\
\hline TKBK 4 & $\checkmark$ & $\checkmark$ & $\checkmark$ \\
TKBK 3 & $\checkmark$ & $\checkmark$ & - \\
& $\checkmark$ & - & $\checkmark$ \\
TKBK 2 & - & $\checkmark$ & - \\
& - & $\checkmark$ & - \\
TKBK 0 & - & - & $\checkmark$ \\
\hline
\end{tabular}

TKBK is the level of creative thinking ability

\section{Result And Discussion}

The results of this data analysis are divided into 2 data, questionnaire and students' creative thinking ability data.

\subsection{Result of Questionnaire}

The results of the needs questionnaire analysis of the learning media based on Blended learning-based from lecturers

Table 2. The need for learning media based on Blended learning.

\begin{tabular}{cccc}
\hline NO & Indicator & Percentage & Criteria \\
\hline 1 & $\begin{array}{c}\text { Availability of facilities for learning } \\
\text { media based on Blended learning }\end{array}$ & $85 \%$ & Adequate \\
2 & $\begin{array}{c}\text { Availability of learning media based } \\
\text { on Blended learning }\end{array}$ & $34 \%$ & inadequate \\
3 & $\begin{array}{c}\text { Response to the availability of } \\
\text { learning media based on Blended learning }\end{array}$ & $97 \%$ & \\
\hline
\end{tabular}

According to table 2., $85 \%$ of lecturers said the availability of facilities for learning media based on Blended learning was sufficient like there is wifi network provided by the university to every study program building. But learning media based on Blended learning inadequately with a percentage of only $34 \%$, and the lecturers' strongly respond to the development of Blended learning based learning media agrees. 
Table 3. The need for learning media based on Blended learning

\begin{tabular}{cccc}
\hline NO & Indicator & Percentage & Criteria \\
\hline 1 & $\begin{array}{c}\text { Availability of facilities for learning } \\
\text { media based on Blended learning }\end{array}$ & $87 \%$ & Adequate \\
2 & $\begin{array}{c}\text { Availability of learning media based } \\
\text { on Blended learning }\end{array}$ & $30 \%$ & Agree \\
3 & $\begin{array}{c}\text { Response to the availability of } \\
\text { learning media based on Blended learning }\end{array}$ & $90 \%$ & \\
\hline
\end{tabular}

The following is the results of the questionnaire analysis of learning media needs based on Blended learning from students.

\subsection{Result of Test}

Following is the result of data analysis of students' creative thinking skills:

Table 2. The result of test creative thinking skills

\begin{tabular}{llll}
\hline No & Creative level & Number & Percentage \\
\hline 1 & Very Creative & 2 & $9 \%$ \\
2 & Creative & 3 & $13 \%$ \\
3 & quite Creative & 5 & $22 \%$ \\
4 & Not Creative & 13 & $56 \%$ \\
Total & & 23 & $100 \%$ \\
\hline
\end{tabular}

Based on table 4 it can be said that students have low creative thinking skills, with $56 \%$ of students not creative and $5 \%$ quite creative.

\subsection{Discussion}

Before the development of learning media on based Blended Learning by using the mentimeter application, first, the researcher analyzed the curriculum. The current curriculum that is used in the odd semester of 2018/2017 school year is the IQF curriculum. This curriculum has been implemented at Medan State University in the 2016/2017 school year. The IQF is a minimum reference framework which is a benchmark for recognition and education levels. This curriculum can integrate between the field of education and the field of training and work experience in the framework of providing recognition of work according to the work structure in every sector.

The implementation of this IQF was changing in the profile of graduates and learning outcomes. Such that it automatically demands changes in the learning model conducted by the lecturer in achieving that specified level. In its qualifications, undergraduate is an education level that is at level 6, with the abilities must have at this level are: 
1. Able to apply their fields of expertise and utilize science, technology, and art in their fields in solving problems and be able to adapt to the situation at hand.

2. Mastering the theoretical concepts of certain fields of knowledge in general and the theoretical concepts of specific parts in the field of knowledge in depth, and able to formulate procedural problem-solving.

3. Able to make the right decisions based on the analysis of information and data, and able to provide instructions in selecting various alternative solutions independently and in groups.

4. Responsible for own work and can be given responsibility for the achievement of organizational work. S

One of the achievements expected at this level is being able to apply their expertise and utilize technology. How can it be realized if during the learning process at university students are not accustomed to utilizing technology? Therefore, based on an analysis of this curriculum, the developer of learning media based on Blended Learning using the mentimeter application is a learning effort by utilizing technological. The habit of learning by using technology gives birth to students who are technologically literate.

The analysis was also carried out on the character of students, student's age average at 17-22 years belong to the age of " $\mathrm{Y}$ " generation or called $\mathrm{Y}$ generation. This generation was born when TV was colored; there were communication tools such as cell phones, Already was familiar with the internet, so that this generation was known as a generation of proficient in technology. This student's characters become big capital to change the style or model of lecturers learning, change to the learning which that can improve creative think them with utilizing technology. Based on it the development of learning media based on Blended learning by using a multimeter application is needed according to the character of the students

Coupled with the results of the analysis, students' creative thinking skills, that have been described earlier in table 4, from 23 students only 5 students who are said to be creative, consisting of 2 students have very creative abilities, 3 in the category creative, the rest are categorized as not creative, 5 students are quite creative, and 13 students are said t no creative thinking ability.

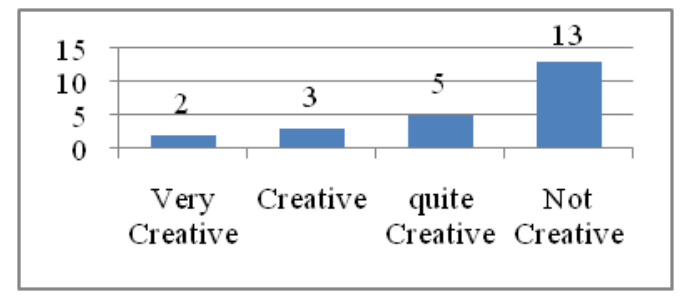

Fig. 1. Diagram of mathematical creative thinking ability test result

Surely this is a problem, why? Mathematical creative thinking ability is one of high order thinking skills, According to Presseisen (Devi, 2011) states that "HOTS (High Order Thinking Skills) are divided into four groups, namely problem solving, decision making, critical thinking, and creative thinking. This creative thinking skill is important for students because of its skill; the student can solve various problems. Assayed by (Sumarmo, 2013) Higher order thinking skills mean a capacity beyond the information provided, actions to critically evaluate, combine cognitive awareness, and can solve problems. 
Therefore must there is a solution to improve creative thinking skills, namely with habituate students to think creatively, developing learning models or developing learning media that can stimulate students always to think creatively.

Both in the curriculum, the character of students and the value of creative abilities of students who need the development of Blended learning based learning media by using the Mentimeter Application.

This conclusion is strengthened by data analysis of questionnaire for needs learning media based on Blended learning. Based on the results of questionnaire data given to lecturers and students which have been described in table 1, and table 2. gives the same opinion from students and from lecturers about needs of media learning based on blended learning using mentimeter application.

Lecturers and students recognize that the facilities that support learning with blended learning are adequate at the State University of Medan, such as computer labs that meet standardization, internet networks that can access from all study programs. Everyone can easily access whatever information they need in learning.

But based on the questionnaire, the availability of learning media based Blended learning is not optimal. The average lecturer still uses media such as focus and utilizes the power point program during college. So the lecturer must be present in class at each lecture meeting when the lecturer collides with another task schedule such as researching or serving. Finally, no one studied in the lecture, and this is a problem. Supposedly with existing facilities, this problem can be minimized by changing the learning model. By utilizing the mentimeter application, students can still study although not at the same time and space with their lecturers.

Seeing the responses given by lecturers and students, they very agree with the availability of learning media based on Blended learning, in this study the application which is tated as blendedlearning media is the mentimeter application. The following picture is one of lecture material in set and logic, figure 3 is the view of mentimeter application at the laptop, while figure 4 is the view of mentimeter application at handphone

To get a deeper analysis, researchers interviewed some lecturers and students, results of the interviews equivalent with the results of the questionnaire needs, both lecturers and students gave a positive response with the existence of media learning based on blended learning by using mentimeter applications.

\section{Conclusions}

According to analysis, blended learning based learning media to improve creative thinking skills by using Mentimeter application must be developed following reasons:

a. The curriculum used at UNIMED is the IQF curriculum, one of the results of the application of this curriculum is a student is technology literacy so that development this media learning is one of means to reach that goal.

b. The age characteristics of students who are in the "Y" generation, namely the generation that is in the era of technological sophistication are the basic capital that facilitates the application of blended learning by using the Mentimeter application

c. The low student's creative skills, so that this media was developed to improve this ability.

d. The availability of facilities that support the availability of learning media and the positive response of lecturers and students to the availability of media. 


\section{References}

[1] Maryland State Department of Education. Maryland Technology Education State Curriculum. [online]. Tersedia di Maryland public schools.or.(2005)

[2] Rudi, S., \& Cepi, R.: Media Pembelajaran. Bandung: Jurusan Kurtekpend FIP UPI (2008)

[3] Azhar Arsyad.: Media Pembelajaran. Jakarta: Rajawali Pers (2011)

[4] Arief S. Sadiman.: Media Pendidikan. Jakarta: PT Raja Grafindo Persada (2008)

[5] Graham, Charles R.: Blended Learning Systems, Definition, Current Trends, and Future Directions. http://www.publicationshare.com/grahamintro (2004)

[6] Koohang, A.: A learner-centered model for blended learning design. International Journal of Innovation and Learning. Vol. 6, pp. 76-91.(2009)

[7] Rusman, dkk.: Pembelajaran Berbasis Teknologi Informasi dan Komunikasi.Jakarta: PT RajaGrafindo Persada. (2011)

[8] Munandar, Utami.: Pengembangan Kreativitas Anak Berbakat. Jakarta:Rineka Cipta. (2012)

[9] Siswono, Tatag Y.E.: Desain Tugas untuk Mengidentifikasi kemampuan berpikir Kreatif Siswa dalam Matematika. Jurusan Matematika FMIPA: Universitas Negeri Surabaya (Online) (2007) Terseida: di Cikgusiber.com. Mentimeter. (2018). [Online] 